\title{
Abnormal Striatal Dopaminergic Neurotransmission during Rest and Task Production in Spasmodic Dysphonia
}

\author{
Kristina Simonyan, ${ }^{1}$ Brian D. Berman, ${ }^{2,3}$ Peter Herscovitch, ${ }^{4}$ and Mark Hallett ${ }^{2}$ \\ ${ }^{1}$ Departments of Neurology and Otolaryngology, Icahn School of Medicine at Mount Sinai, New York, New York 10029, ${ }^{2}$ Human Motor Control Section, \\ Medical Neurology Branch, National Institute of Neurological Disorders and Stroke, National Institutes of Health, Bethesda, Maryland 20892, ${ }^{3}$ Department \\ of Neurology, University of Colorado Anschutz Medical Campus, Denver, Colorado 80045, and 4PET Department, Clinical Center, National Institutes of \\ Health, Bethesda, Maryland 20892
}

Spasmodic dysphonia is a primary focal dystonia characterized by involuntary spasms in the laryngeal muscles during speech production. The pathophysiology of spasmodic dysphonia is thought to involve structural and functional abnormalities in the basal gangliathalamo-cortical circuitry; however, neurochemical correlates underpinning these abnormalities as well as their relations to spasmodic dysphonia symptoms remain unknown. We used positron emission tomography with the radioligand [ $\left.{ }^{11} \mathrm{C}\right] \mathrm{raclopride}(\mathrm{RAC})$ to study striatal dopaminergic neurotransmission at the resting state and during production of symptomatic sentences and asymptomatic finger tapping in spasmodic dysphonia patients. We found that patients, compared to healthy controls, had bilaterally decreased RAC binding potential (BP) to striatal dopamine $\mathrm{D}_{2} / \mathrm{D}_{3}$ receptors on average by $29.2 \%$, which was associated with decreased RAC displacement (RAC $\triangle \mathrm{BP}$ ) in the left striatum during symptomatic speaking (group average difference $10.2 \%$ ), but increased RAC $\Delta \mathrm{BP}$ in the bilateral striatum during asymptomatic tapping (group average difference $10.1 \%$ ). Patients with more severe voice symptoms and subclinically longer reaction time to initiate the tapping sequence had greater RAC $\Delta \mathrm{BP}$ measures, while longer duration of spasmodic dysphonia was associated with a decrease in task-induced RAC $\triangle \mathrm{BP}$. Decreased dopaminergic transmission during symptomatic speech production may represent a disorder-specific pathophysiological trait involved in symptom generation, whereas increased dopaminergic function during unaffected task performance may be explained by a compensatory adaptation of the nigrostriatal dopaminergic system possibly due to decreased striatal $D_{2} / D_{3}$ receptor availability. These changes can be linked to the clinical and subclinical features of spasmodic dysphonia and may represent the neurochemical basis of basal ganglia alterations in this disorder.

\section{Introduction}

Spasmodic dysphonia is a primary task-specific focal dystonia characterized by involuntary spasms in the laryngeal muscles, which lead to uncontrolled voice breaks predominantly during speaking (Bloch et al., 1985). The pathophysiology of spasmodic dysphonia and other primary dystonias is generally thought to involve abnormalities in the basal ganglia, sensorimotor and cerebellar networks (Berardelli et al., 1998; Hallett, 1998; Defazio et al., 2007; Neychev et al., 2011). However, the neurochemical underpinnings of these abnormalities remain poorly understood.

It has been suggested that abnormally increased or decreased dopamine levels may modulate striatal synaptic plasticity in

\footnotetext{
Received Jan. 28, 2013; revised July 26, 2013; accepted Aug. 2, 2013

Author contributions: K.S., P.H., and M.H. designed research; K.S. and B.D.B. performed research; K.S. analyzed data; K.S. wrote the paper.

This work was supported by NIDCD Grant R00DC009629 (K.S.), the Intramural Program of the National Institute of Neurological Disorders and Stroke, and the NIH Clinical Center. We thank Sandra B. Martin for assistance with patient recruitment and rating of the voice and speech samples, Dr. Pamela R. Kearney for participants' clinical evaluation, Richard Reynolds for help with data processing, and the staff at the PET Department of the NIH Clinical Center for assistance with PET data acquisition.

The authors declare no competing financial interests.

Correspondence should be addressed to Dr. Kristina Simonyan, Department of Neurology, One Gustave L. Levy Place, Box 1137, Icahn School of Medicine at Mount Sinai, New York, NY 10029. E-mail: kristina.simonyan@mssm.edu.

D0I:10.1523/JNEUROSCI.0407-13.2013

Copyright $\odot 2013$ the authors $\quad 0270-6474 / 13 / 3314705-10 \$ 15.00 / 0$
}

dystonia (Todd and Perlmutter, 1998; Hallett, 2004; Breakefield et al., 2008; Peterson et al., 2010), while decreased $\mathrm{D}_{2}$ receptormediated inhibition may alter the balance between basal ganglia excitation and inhibition, cause disinhibiton of the thalamocortical circuitry, and contribute to dystonic muscle contractions during performance of fine motor tasks (Lenz et al., 1998; Defazio et al., 2007). Accordingly, decreased striatal dopamine $\mathrm{D}_{2} / \mathrm{D}_{3}$ receptor binding at rest was found in patients with cranial, cervical, and focal hand dystonias (Horstink et al., 1997; Perlmutter et al., 1997; Naumann et al., 1998; Berger et al., 2007; Horie et al., 2009) as well as manifesting and nonmanifesting DYT1 and DYT6 mutation carriers (Augood et al., 2002; Asanuma et al., 2005; Carbon et al., 2009). It is likely that these patients may also have altered dopamine release during task production; however, the extent of dopaminergic abnormalities during symptom generation has not yet been reported in either spasmodic dysphonia or other primary dystonias. Our knowledge remains also limited in regard to the dopaminergic influences on clinical manifestation of dystonic symptoms, as only a few studies have described minimal, if any, correlations between decreased $\mathrm{D}_{2} / \mathrm{D}_{3}$ receptor binding and severity/duration of dystonia (Horstink et al., 1997; Naumann et al., 1998; Carbon et al., 2009; Horie et al., 2009).

The goal of this study was to investigate striatal dopaminergic transmission in patients with spasmodic dysphonia compared to healthy controls during resting as well as symptomatic sentence 
Table 1. Demographic and clinical characteristics of participants

\begin{tabular}{|c|c|c|c|}
\hline & $\begin{array}{l}\text { Spasmodic } \\
\text { dysphonia } \\
\text { patients }\end{array}$ & $\begin{array}{l}\text { Healthy } \\
\text { controls }\end{array}$ & $\begin{array}{l}p \\
\text { value }\end{array}$ \\
\hline \multicolumn{4}{|l|}{ Demographic characteristics } \\
\hline \multicolumn{4}{|l|}{ Speech production RAC PET } \\
\hline Number of participants & 18 & 18 & \\
\hline Age & $54.6 \pm 11.0$ & $54.6 \pm 9.2$ & 0.99 \\
\hline Gender & $12 \mathrm{~F} / 6 \mathrm{M}$ & $12 \mathrm{~F} / 6 \mathrm{M}$ & 1.00 \\
\hline Handedness & Right & Right & \\
\hline Spoken language & English & English & \\
\hline Other language experience & None & None & \\
\hline \multicolumn{4}{|l|}{ Sequential finger tapping RAC PET } \\
\hline Number of participants & 15 & 15 & \\
\hline Age & $54.6 \pm 9.2$ & $54.4 \pm 9.5$ & 0.97 \\
\hline Gender & $10 \mathrm{~F} / 5 \mathrm{M}$ & $9 \mathrm{~F} / 6 \mathrm{M}$ & 0.72 \\
\hline \multicolumn{4}{|l|}{ Clinical characteristics } \\
\hline Other forms of dystonia & None & None & \\
\hline Number of symptomatic patients & 18 & $\mathrm{~N} / \mathrm{A}$ & \\
\hline $\begin{array}{l}\text { Number of patients on botulinum toxin } \\
\text { treatment }\end{array}$ & 17 & $\mathrm{~N} / \mathrm{A}$ & \\
\hline Spasmodic dysphonia duration & $13.3 \pm 7.3$ & $\mathrm{~N} / \mathrm{A}$ & \\
\hline $\begin{array}{l}\text { Spasmodic dysphonia severity (voice } \\
\text { breaks per sentence) }\end{array}$ & $2.4 \pm 1.8$ & $\mathrm{~N} / \mathrm{A}$ & \\
\hline Number of finger taps & $4245 \pm 861$ & $4140 \pm 966$ & 0.37 \\
\hline Accuracy of finger taps (\%) & $84.4 \pm 11.9$ & $86.4 \pm 13.7$ & 0.34 \\
\hline $\begin{array}{l}\text { Initiation of the tapping sequence } \\
\text { (reaction time value for mean } \\
\text { linear slope coefficient) }\end{array}$ & $0.2 \pm 0.3$ & $-0.2 \pm 0.3$ & 0.006 \\
\hline
\end{tabular}

F, Female; $M$, male.

production and asymptomatic sequential finger tapping. We used positron emission tomography (PET) with the radioligand $\left[{ }^{11} \mathrm{C}\right]$ raclopride (RAC) to examine its binding potential (BP) to striatal dopamine $\mathrm{D}_{2} / \mathrm{D}_{3}$ receptors, RAC displacement (RAC $\Delta \mathrm{BP}$ ) by task-induced dopamine release, and their relationships with clinical and subclinical features of spasmodic dysphonia. RAC BP reflects a ratio of receptor density to affinity $\left(B_{\max } / K_{\mathrm{D}}\right)$ and provides information about the receptor availability, whereas RAC $\triangle B P$ reflects competitive inhibition of RAC binding by endogenously released dopamine and/or noncompetitive interactions (Laruelle, 2000; Ginovart, 2005).

We hypothesized that patients with spasmodic dysphonia would have decreased RAC binding to striatal dopamine $\mathrm{D}_{2} / \mathrm{D}_{3}$ receptors at rest, which would reflect decreased receptor density or increased intrinsic dopamine levels (Seeman et al., 1989; Volkow et al., 1994). This may be associated with altered dopamine release during task production. Based on our previous findings of abnormal functional activity during both symptomatic and asymptomatic tasks in spasmodic dysphonia (Simonyan and Ludlow, 2010), we expected to identify changes in RAC $\Delta \mathrm{BP}$ during both symptomatic speaking and asymptomatic finger tapping. We hypothesized that some of these abnormalities may be linked to clinical and subclinical features of spasmodic dysphonia, possibly contributing to the manifestation of this disorder.

\section{Materials and Methods}

Subjects. Eighteen patients with an adductor type of spasmodic dysphonia ( 12 females, 6 males; age, $54.6 \pm 11.0$ years; mean \pm SD) and 18 age- and gender-matched healthy volunteers ( 12 females, 6 males; age, $54.6 \pm 9.2$ years; mean $\pm \mathrm{SD}$ ) participated in the study (Table 1). All subjects were right-handed on the Edinburgh Handedness Inventory (Oldfield, 1971) and monolingual native English speakers. The participants had no neurological (except spasmodic dysphonia in the patient group), psychiatric, or laryngeal problems based on history and physical examination. All patients were fully symptomatic at the time of study participation, which was confirmed by voice and speech acoustic analysis and fiber-optic nasolaryngoscopy. Among them, 17 patients had been on a regimen of botulinum toxin injections into their laryngeal muscles to manage their voice symptoms; one patient had not been treated previously with botulinum toxin. Those patients, who received regular botulinum toxin treatment, were recruited at least 3 months after the most recent injection, when laryngeal symptoms were present and confirmed clinically. The mean duration of spasmodic dysphonia was $13.3 \pm 7.3$ years (mean $\pm \mathrm{SD}$ ), which was established from the time of voice symptom onset during history and physical examination. Clinical neuroradiological evaluation of MRI in both healthy controls and patients found normal brain structure without any gross abnormalities.

All subjects provided written informed consent before participation in the study, which was approved by the Institutional Review Boards of the Icahn School of Medicine at Mount Sinai and National Institutes of Health, and the NIH Radiation Safety Committee. Similar experiments were done at about the same time with patients with writer's cramp, and some control subjects were shared across the two studies (Berman et al., 2013). Data from some control subjects were also reported in our previous study (Simonyan et al., 2013).

Experimental tasks. Two separate PET scans with RAC, which is a reversible dopamine $\mathrm{D}_{2} / \mathrm{D}_{3}$ receptor antagonist, were performed to examine dopaminergic function at rest and during symptomatic sentence production and asymptomatic sequential finger tapping. During the initial 100 min scan, subjects rested with their eyes closed in a quiet environment in the PET scanner suite with ambient light for $50 \mathrm{~min}$ and then produced short English sentences for the remaining $50 \mathrm{~min}$ (Fig. 1A). The sentences (e.g., "Tom is in the army," "Are the olives large?") induced voice symptoms in all patients due to a high number of glottal stops preceding vowels. Subjects were instructed to listen attentively to an acoustically presented sample sentence and repeat each sentence four times at the comfortable conversational speech level. Ten different sentences were recorded from a native English female speaker for the purposes of this study, pseudorandomized between subjects, and presented one at a time. Subjects performed repetition of different sentences continuously for $4 \mathrm{~min}$ and rested for $1 \mathrm{~min}$ to avoid boredom. No acoustical stimulus was presented during the 1 min resting period (Fig. 1A). Each subject was instructed to speak without head movements, which were additionally minimized by using a comfortably tight thermoplastic mask molded around the subject's head.

To assess the differences in dopaminergic transmission during performance of an unaffected motor task between patients with spasmodic dysphonia and healthy controls, 15 of the same subjects per group (controls, 9 females, 6 males; age, $54.4 \pm 9.5$ years; spasmodic dysphonia, 10 females, 5 males; age, $54.6 \pm 9.2$ years; mean $\pm S D$ ) returned for the second RAC PET scan using a similar scanning paradigm (Fig. 1B, Table 1). Following the $50 \mathrm{~min}$ resting baseline, subjects were instructed to perform sequential finger tapping (i.e., 1-2-3-4-5-4-3-2-1) using the dominant right hand. Subjects were cued to start finger tapping by a double beep tone and stop when a single beep tone was presented. All subjects performed finger tapping for $40 \mathrm{~s}$ on a fiber-optic button response unit (Celeritas; Psychology Software Tools), which was followed by a $10 \mathrm{~s}$ resting period to avoid boredom. The task production, including the incorporated $10 \mathrm{~s}$ resting between the tasks, lasted for $50 \mathrm{~min}$. The finger-tapping task was asymptomatic in all patients.

Data acquisition and analysis. All subjects were instructed not to drink any beverages containing caffeine within $24 \mathrm{~h}$ of scanning and to fast for $3 \mathrm{~h}$ before the PET scan. Scanning sessions were initiated in the morning (between 8:30 A.M. and 11:30 A.M.) to control for possible diurnal variations in dopamine transmission. In subjects receiving two RAC PET scans, both were performed within a year.

All PET data were acquired on a GE Advance tomograph (GE Medical Systems). Initially, an 8 min transmission scan was obtained using a ${ }^{68} \mathrm{Ge}$ source for attenuation correction of emission data, followed by the administration of RAC as a $1 \mathrm{~min}$ bolus and subsequent 99 min constant infusion (bolus-plus-infusion method; Watabe et al., 2000) using a computer-operated pump (Harvard Instruments; Fig. 1). Accounting for the decay, an average injected RAC dose during the speech production 


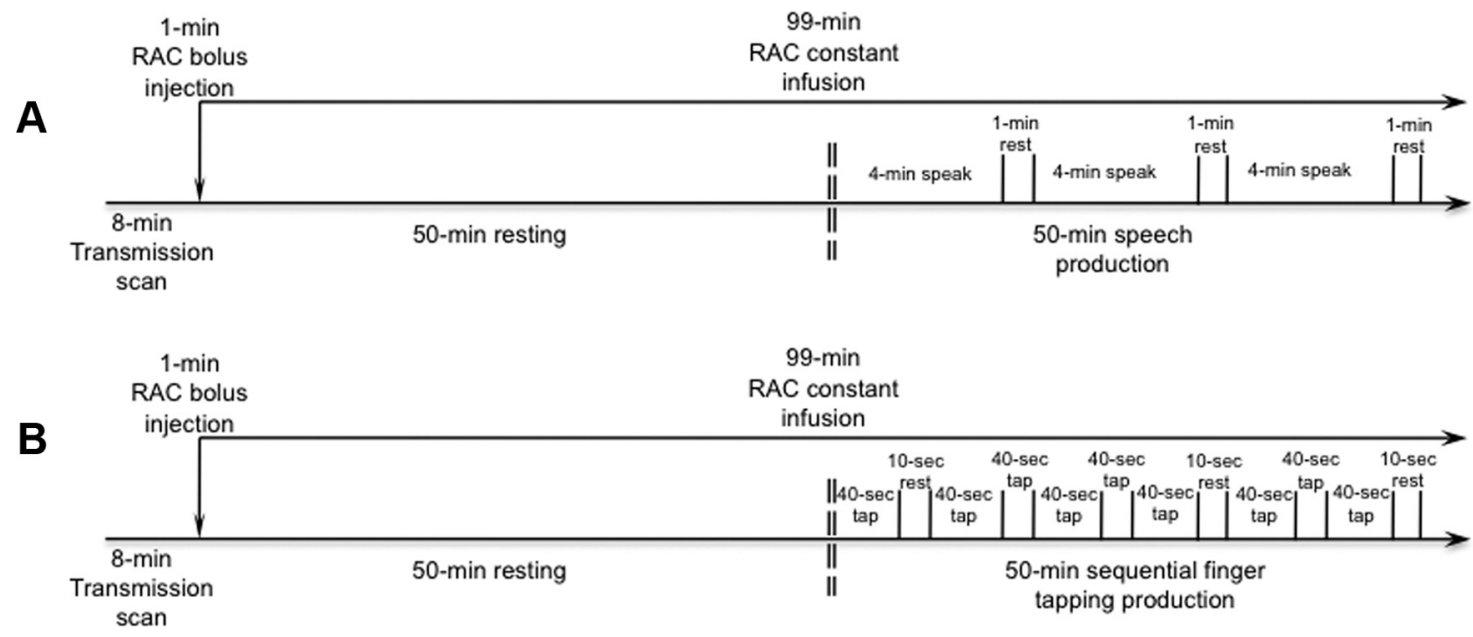

Figure 1. $\quad A, B$, Schematic illustration of the experimental design of PET scans with $\left[{ }^{11} \mathrm{C}\right]$ raclopride radioligand during symptomatic sentence production $(\boldsymbol{A})$ and asymptomatic sequential finger tapping (B).

scan was $20.2 \pm 0.4 \mathrm{mCi}$ (mean $\pm \mathrm{SD}$ ) with the specific activity of $2851.1 \pm 1242.9 \mathrm{mCi} / \mu \mathrm{mol}$ in patients and $19.7 \pm 1.4 \mathrm{mCi}$ with the specific activity $2415.6 \pm 1207.1 \mathrm{mCi} / \mu \mathrm{mol}$ in healthy controls. During the finger-tapping scan, an average injected RAC dose was $19.4 \pm 1.6$ $\mathrm{mCi}$ with the specific activity of $3553.3 \pm 1924.4 \mathrm{mCi} / \mu \mathrm{mol}$ in patients and $20.4 \pm 0.3 \mathrm{mCi}$ with the specific activity of $3796.5 \pm 2158.3 \mathrm{mCi} /$ $\mu \mathrm{mol}$ in healthy controls. There were no statistically significant differences in the tracer conditions between the patient and control groups (all $p \geq 0.29$ ). At the start of RAC bolus injection, a dynamic PET scan was initiated in the 3D scanning mode with septa retracted and continued for the duration of RAC infusion, acquiring 27 time frames of $30 \mathrm{~s}$ to $5 \mathrm{~min}$ epochs over a total of $100 \mathrm{~min}(\mathrm{FOV}=148 \mathrm{~mm}$; reconstructed resolution, $6 \mathrm{~mm}$ in all direction).

Additionally, all subjects underwent a separate MRI scan to obtain high-resolution T1-weighted images for individual anatomical reference (3D magnetization prepared rapid acquisition gradient echo sequence with TI, $450 \mathrm{~ms}$; TE, $3.0 \mathrm{~ms}$; flip angle, $10^{\circ}$; bandwidth, $31.25 \mathrm{~mm}$; FOV, $240 \mathrm{~mm}$; matrix, $256 \times 256 \mathrm{~mm} ; 128$ contiguous axial slices; slice thickness, $1.2 \mathrm{~mm}$ ).

As an initial step in data analysis, we corrected for possible head motion-induced artifacts during task performance using the registered attenuation correction method. After reconstruction of emission images with filtered backprojection with no attenuation correction, all emission frames were registered with mutual information to the prime emission image using the FLIRT toolbox of the FSL software package. The transmission images were further registered to the same prime emission image, and the emission frame was reconstructed with filtered backprojection to be used for attenuation correction. The emission image was resliced back to the transmission position, thus correcting for motion. In addition, individual quality indices were calculated for all preprocessed data using the AFNI software package to ensure that there were no other remaining residual head motions, which may introduce artifacts in the acquired images.

The final motion- and decay-corrected PET images were averaged over the 40-50 min time interval of baseline and over 60-100 min of task production using PMOD Technologies software as described previously (Garraux et al., 2007; Simonyan et al., 2013). In each subject, PET data sets were aligned to individual high-resolution T1-weighted MR images using Hellinger distance and the two-pass alignment method, and further normalized to a standard Talairach-Tournoux space using PMOD Technologies and AFNI software packages.

To examine the RAC BP during resting and its changes due to task production (i.e., speaking and finger tapping), we calculated parametric voxelwise striatal RAC BP maps for each condition using the equilibrium ratio of bound ligand to free and nonspecifically bound tracer under the assumption that nonspecific binding is uniform throughout the brain. The equation $\mathrm{BP}_{\mathrm{ND}}=\left(C-C^{\prime}\right) / C^{\prime}$, where $\mathrm{ND}$ indicates free and non- specific concentrations, was based on the radioactivity concentration in the striatum $(C)$ as a region with the highest density of dopamine $\mathrm{D}_{2} / \mathrm{D}_{3}$ receptors and the cerebellum $\left(C^{\prime}\right)$ as a region devoid of $\mathrm{D}_{2} / \mathrm{D}_{3}$ receptors. The striatal and cerebellar regions were outlined using the probabilistic macrolables atlas of the Anatomy Toolbox (Eickhoff et al., 2005) as described previously (del Campo et al., 2011; Salimpoor et al., 2011; Simonyan et al., 2013). Based on this atlas, the dorsal striatum, including the putamen and caudate nucleus, was sampled at its entire rostrocaudal and dorsoventral extents; the cerebellar region included gray matter defined on five consecutive slices of both hemispheres. To account for influences of possible outliers on RAC BP signal variance, which might affect the statistical differences on group comparisons, we calculated voxelwise median absolute deviations (MADs) and examined the range of median $\pm 3.5^{*}$ MAD for each data set using AFNI software. Subjects with RAC BP values outside of this range were considered outliers and removed from the further processing steps. We found that one subject per each group had RAC BP values outside the normal range and, therefore, were eliminated from the corresponding groups. Using the data sets of remaining 17 subjects in each group, the differences between spasmodic dysphonia patients and controls in RAC BP during resting were assessed using a voxelwise two-sample independent $t$ test at an FWE-corrected value of $p \leq 0.017$ with a minimal cluster size extent of 100 voxels as determined using Monte Carlo simulations in AFNI (Forman et al., 1995). This overall $\alpha$ level of $p \leq 0.017$ was chosen to take into account three different comparisons of RAC BP (i.e., during resting, speaking, and tapping) between the two groups.

To estimate changes in RAC binding during task performance, we used the statistical parametric maps of $\mathrm{RAC} \mathrm{BP}_{\mathrm{ND}}$ during resting and the respective task to calculate the percentage change in $\mathrm{RAC} \mathrm{BP}_{\mathrm{ND}}\left(\Delta \mathrm{BP}_{\mathrm{ND}}\right)$ in each subject using the equation $\Delta \mathrm{BP}=\left(\mathrm{BP}_{\text {speech/tapping }}-\mathrm{BP}_{\text {resting }}\right) /$ $\mathrm{BP}_{\text {resting }} \times 100 \%$ (Watabe et al., 2000). The obtained negative values of RAC $\triangle \mathrm{BP}$ indicated the percentage of displacement of RAC by endogenously released dopamine, with the greater negative values corresponding to the greater RAC displacement. Two separate between-group comparisons of $\triangle \mathrm{BP}_{\mathrm{ND}}$ during speaking and finger tapping, respectively, were conducted using voxelwise two-sample independent $t$ tests at an FWE-corrected value of $p \leq 0.025$, with a minimal cluster size extent of 50 voxels.

Relationship between RAC BP measures and task performance. During the PET experiments, the subjects' performance was recorded for correlation analyses between RAC BP measures and symptomatic/asymptomatic task production. Symptomatic sentence production was recorded in all subjects using an omnidirectional microphone (ECM-44B; Sony) attached to the tomograph's bore in a constant position from the subject's head. Data were digitized online using LabChart 7 Pro software (ADInstruments). Patients' speech recordings were anonymized and randomized for blinded analysis of the severity of spasmodic dysphonia 
symptoms by an experienced speech-language pathologist. The presence of spasmodic dysphonia-characteristic voice breaks in sentences was measured by counting the number of spasmodic dysphonia breaks (Bielamowicz and Ludlow, 2000; Barkmeier et al., 2001). Because healthy controls did not have any voice or speech abnormalities, their sentence performance was not rated. Using AFNI software, voxelwise striatal Spearman's rank correlation coefficients were computed to assess the statistical dependence of RAC BP at rest and RAC $\Delta \mathrm{BP}_{\mathrm{ND}}$ during symptomatic speech production with the number of spasmodic dysphoniacharacteristic voice breaks at a corrected value of $p \leq 0.025$. To account for possible influences on correlation coefficients by a few points, a jackknife procedure was performed to exclude any correlation coefficients that are statistically significant due to the presence of an outlier, as described previously (Horwitz et al., 1986, 1991; Simonyan et al., 2013).

Asymptomatic finger tapping was performed on the button response unit and digitized using the LabChart 7 Pro software. Although finger tapping was recorded in all subjects, only data from 15 patients and 13 healthy controls were usable due to the technical problems in 2 controls. Blinded finger tapping data were analyzed in both healthy controls and patients to derive the measures of the total number of performed taps and accuracy of the sequence performance using automated scripts developed in-house (Matlab R2010b; MathWorks) as well as a measure of the reaction time (RT) to the task initiation using the Peak Analysis module in LabChart 7 Pro software. To account for within-subject and betweengroup RT variability, each subject's RT measure was fitted using linear regression, and the obtained measures were converted to $z$-scores using a Fisher's transformation. Between-group differences on these three measures (i.e., number of taps, accuracy of performance, and RT) were assessed using independent two-sample $t$ tests at $p \leq 0.017$ to correct for multiple comparisons. The parameters, which were significantly different between the two groups, were examined for their relationships with the RAC BP at rest and RAC $\triangle \mathrm{BP}_{\mathrm{ND}}$ during sequential finger tapping using voxelwise Spearman's rank order correlation analyses with a jackknife resampling at a corrected value of $p \leq 0.025$.

Finally, the duration of spasmodic dysphonia was examined for its relationship with RAC BP at rest and RAC $\triangle \mathrm{BP}_{\mathrm{ND}}$ during production of both tasks using Spearman's rank order correlation analyses with a jackknife procedure at a corrected value of $p \leq 0.017$.

\section{Results}

\section{Behavioral measurements}

In patients with spasmodic dysphonia, symptomatic sentence production during the RAC PET scan elicited $2.4 \pm 1.8$ (mean \pm $\mathrm{SD}$ ) voice breaks per each sentence produced, ranging in all sentences from 11 breaks in the mildest case to 191 breaks in the most severe case (Table 1). Sentence production in healthy controls was normal without any spasmodic dysphonia-characteristic or other voice and speech symptoms.

Sequential finger tapping was fully asymptomatic in patients, whose performance of the number of taps (spasmodic dysphonia, $4245 \pm 861$; controls, $4140 \pm 966$, mean $\pm \mathrm{SD} ; p=0.37$ ) and the accuracy of performed tapping sequence (spasmodic dysphonia, $84.4 \pm 11.9 \%$; controls, $86.4 \pm 13.7 \% ; p=0.34$ ) did not differ significantly from healthy controls. However, patients with spasmodic dysphonia had a statistically significant delay in the initiation of the experimental sequence as determined by a positive RT value for the mean linear slope coefficient compared to a negative RT value for the mean linear slope coefficient in controls (spasmodic dysphonia, $0.2 \pm 0.3$; controls, $-0.2 \pm 0.3 ; p=$ 0.006; Table 1).

Duration of the disorder $(13.3 \pm 7.3$ years $)$ did not show significant correlations with either the severity of symptoms ( $r=$ $-0.21 ; p=0.40)$ or the delay in the initiation of the tapping sequence $(r=-0.007 ; p=0.98)$. This may be explained by the fact that spasmodic dysphonia symptoms typically plateau within the first year after the onset and remain unchanged for life in the majority of patients, while only a subset of patients reports worsening or improvement of their symptoms over time (Izdebski et al., 1984; Aronson, 1990; Tanner et al., 2011). In this study, all patients with spasmodic dysphonia had stable symptoms for at least 6 years, and none reported significant progression of their voice symptoms. Our findings thus substantiate the clinical observation that patients, at least in this cohort, did not have major changes of their voice symptoms as well as subclinical features over the duration of their disorder.

\section{Decreased RAC binding to striatal dopamine $D_{2 / 3}$ receptors during resting in patients with spasmodic dysphonia}

As has been shown previously, striatal dopamine $\mathrm{D}_{2 / 3}$ receptor distribution and tonic release of endogenous dopamine may be assessed using the baseline RAC BP measurements at the resting state, whereas the task-related transient phasic dopamine release may be captured using the measure of RAC $\Delta \mathrm{BP}_{\mathrm{ND}}$ in response to a pharmacological or behavioral challenge (in this case, speech production/finger tapping vs rest; Breier et al., 1997; Carson et al., 1997; Laruelle, 2000; Wong et al., 2008; Egerton et al., 2009).

Voxelwise analysis of striatal RAC BP during resting showed that patients with spasmodic dysphonia, compared to healthy controls, had decreased RAC BP by $25.8 \%$ in the left putamen and $25.7 \%$ in the right putamen (left, spasmodic dysphonia, $1.8 \pm 0.5$; controls, $2.4 \pm 0.5 ; p=0.001$; right, spasmodic dysphonia, $1.7 \pm 0.5$; controls, $2.3 \pm 0.4 ; p=0.0007$; mean $\pm \mathrm{SD}$ ) as well as $31.8 \%$ in the left caudate nucleus and $33.6 \%$ in the right caudate nucleus (left, spasmodic dysphonia, $1.0 \pm 0.5$; controls, $1.5 \pm 0.4 ; p=0.005 ;$ right, spasmodic dysphonia, $0.9 \pm 0.5$; controls, $1.3 \pm 0.3 ; p=0.007$; mean $\pm \mathrm{SD}$ ) at an overall corrected value of $p \leq 0.017$ (Fig. $2 A$, Table 2). There were no significant differences in the RAC BP measures in either controls or patients between the two resting scans obtained before speech and tapping productions, respectively.

\section{Decreased RAC $\Delta \mathrm{BP}_{\mathrm{ND}}$ during symptomatic speech production but increased RAC $\triangle \mathrm{BP}$ during asymptomatic finger tapping in patients with spasmodic dysphonia} During task production, compared to the resting baseline, both groups showed decreased RAC binding to striatal $\mathrm{D}_{2} / \mathrm{D}_{3}$ receptors due to its displacement by endogenous dopamine release. However, during symptomatic sentence production, RAC displacement (RAC $\triangle \mathrm{BP}_{\mathrm{ND}}$ ) was less in patients with spasmodic dysphonia than controls in the left putamen by $6.7 \%$ (mean $\Delta \mathrm{BP}_{\mathrm{ND}}$, spasmodic dysphonia, $-5.7 \%$; controls, $-12.4 \% ; p=$ 0.017 ) and left caudate nucleus by $13.7 \%$ (mean $\Delta \mathrm{BP}_{\mathrm{ND}}$, spasmodic dysphonia, $-3.5 \%$; controls, $-17.2 \% ; p=0.003)$ at an overall corrected value of $p \leq 0.025$ (Fig. 2B, Table 2). No significant differences between the two groups were found in the right striatum.

As hypothesized, clinically asymptomatic sequential finger tapping was also found to be associated with abnormal RAC $\Delta \mathrm{BP}_{\mathrm{ND}}$ in patients with spasmodic dysphonia. However, in contrast to symptomatic speech production, $\mathrm{RAC} \Delta \mathrm{BP}_{\mathrm{ND}}$ was greater in patients with spasmodic dysphonia than controls by 9.6 and $6.7 \%$ in the left and right putamina, respectively (mean $\Delta \mathrm{BP}_{\mathrm{ND}}$, left, spasmodic dysphonia, $-11.0 \%$; controls, $-1.5 \% ; p=$ 0.0007 ; right, spasmodic dysphonia, $-11.0 \%$; controls, $-5.3 \%$; $p=0.0008$ ) and by 15.0 and $10.0 \%$ in the left and right caudate nuclei, respectively (mean $\Delta \mathrm{BP}_{\mathrm{ND}}$, left, spasmodic dysphonia, $-17.9 \%$; controls, $-2.9 \% ; p=0.019$; right, spasmodic dysphonia, $-10.8 \%$; controls, $-0.9 \% ; p=0.006)$ at an overall corrected value of $p \leq 0.025$ (Fig. 2C, Table 2). 


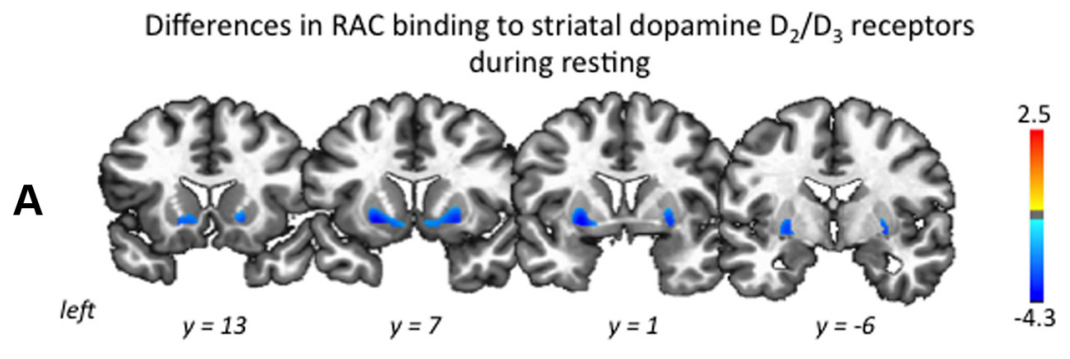

Differences in displacement of RAC by dopamine release during symptomatic speech production

B

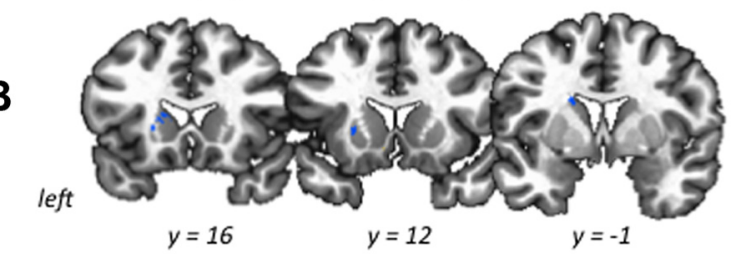

Differences in displacement of RAC by dopamine release during

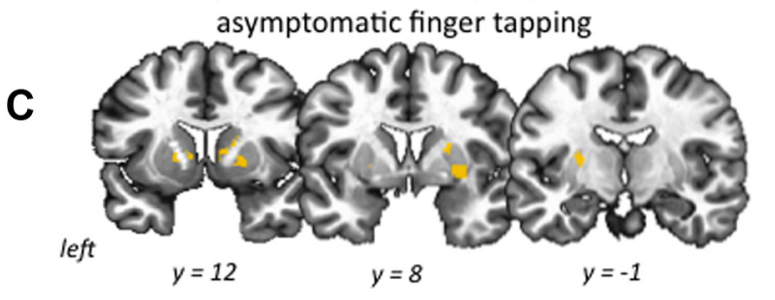

Figure 2. $\quad \boldsymbol{A}-\boldsymbol{C}$, Group difference in $\mathrm{RAC}$ binding at rest $(\boldsymbol{A})$ and its change (mean percentage $\triangle B P$ ) during symptomatic speech production $(\boldsymbol{B})$ and asymptomatic sequential finger tapping $(\boldsymbol{C})$. The color bars represent the $t$ values and reflect the significance of changes in striatal RAC BP measures in spasmodic dysphonia patients compared to healthy controls (spasmodic dysphonia $<$ healthy control, dark blue to light blue; spasmodic dysphonia $>$ healthy control, yellow to red). All statistical maps are shown in the series of coronal brain images in Talairach-Tournoux standard space.

\section{Relationships between the clinical features of spasmodic dysphonia and RAC binding measures}

The duration of spasmodic dysphonia was not correlated with RAC BP measure at the resting state, but established significant correlations with RAC $\triangle \mathrm{BP}_{\mathrm{ND}}$ during the performance of both symptomatic and asymptomatic tasks. During symptomatic speech production, significant negative relationships between the disorder duration and RAC $\triangle \mathrm{BP}_{\mathrm{ND}}$ were found in the left putamen (jackknife estimated $r_{\mathrm{s}}=-0.72$ ) and left caudate nucleus (jackknife estimated $r_{\mathrm{s}} \geq-0.68$ ) at a corrected value of $p \leq 0.017$ (Fig. 3A). Because the duration of spasmodic dysphonia in our patient population ranged from 6 to 31 years, we further examined the significance of these correlations in separate groups of patients with $<15$ and $>15$ years of the disorder duration. Correlations in the left putamen were significantly stronger among the patients with shorter duration of spasmodic dysphonia (jackknife estimated $r_{\mathrm{s}}=$ 0.31 vs $-0.41 ; p=0.008$ ), while correlations in the caudate nucleus were stronger in patients with longer disorder duration (jackknife estimated $\left.r_{\mathrm{s}}=-0.90 \mathrm{vs}-0.62 ; p=0.025\right)$.

During asymptomatic finger tapping, a significant positive relationship between the duration of spasmodic dysphonia and RAC $\Delta \mathrm{BP}_{\mathrm{ND}}$ was also observed in the left caudate nucleus (jackknife estimated $r_{\mathrm{s}}=0.75$ ) at a corrected value of $p \leq 0.017$ (Fig. $3 B$ ). The correlation coefficients showed no difference between the groups of patients with shorter and longer durations of the disorder $(p=0.06)$.

When examining the severity of spasmodic dysphonia, no statistically significant relationships were found between the de-

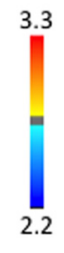

creased RAC BP at rest and disorderspecific voice breaks or delayed initiation of the tapping sequence. However, positive relationships were established between RAC $\Delta \mathrm{BP}_{\mathrm{ND}}$ during speaking and the severity of symptoms (assessed as the number of voice breaks during sentence production) in the left putamen (jackknife estimated $r_{\mathrm{s}}=0.59$ ) and right caudate nucleus (jackknife estimated $\left.r_{\mathrm{s}}=0.61\right)$ at a corrected value of $p \leq$ 0.025 (Fig. 4A). There were no statistical differences in the RAC $\Delta \mathrm{BP}_{\mathrm{ND}}$ measures between the patients with mild ( $<50$ breaks in all sentences produced), moderate (50-100 breaks) or severe $(>100$ breaks) disorder symptoms (all $p \geq 0.10$ ). However, when examining these values in relationship with the degree of symptom severity, we found that severe patients with the high number of voice breaks ( $>100$ breaks) had a significant positive correlation between their symptoms and RAC $\Delta \mathrm{BP}_{\mathrm{ND}}$ in the left caudate nucleus (jackknife estimated $r_{\mathrm{s}}=0.48$ ) and a weak positive correlation in the left putamen (jackknife estimated $r_{\mathrm{s}}=$ $0.20)$. Conversely, patients with the moderate symptom severity (50-100 breaks) showed a weak positive correlation in the left caudate nucleus (jackknife estimated $\left.r_{\mathrm{s}}=0.19\right)$, but a significant negative correlation in the left putamen (jackknife estimated $\left.r_{\mathrm{s}}=-0.58\right)$. Patients with mild symptom severity ( $<50$ breaks) had only negative relationships between their symptoms and RAC displacement in the both left putamen and caudate nucleus (both jackknife estimated $r_{\mathrm{s}}=$ -0.60 ). This suggests that the overall positive relationships initially observed between the severity of spasmodic dysphonia and RAC $\Delta \mathrm{BP}_{\mathrm{ND}}$ may have been influenced by the presence of severe patients in this cohort.

In addition, a negative relationship was found between RAC $\triangle \mathrm{BP}_{\mathrm{ND}}$ during finger tapping and delayed initiation of tapping sequence in the right putamen (jackknife estimated $r_{\mathrm{s}} \geq-0.60$ ) at a corrected value of $p \leq 0.025$ (Fig. 4B). This indicates that patients with longer reaction times may have generated higher levels of striatal dopamine release during task execution. There were no statistical differences in these correlations due to the presence of negative RT values for the mean linear slope coefficient in a few patients with spasmodic dysphonia compared to those with the positive RT values (all $p \geq 0.21$ ). Together, these results suggest that abnormalities of task-dependent dopamine release may fluctuate relative to symptom production, from abnormally low levels in mild cases to higher levels in more severe cases.

\section{Discussion}

We demonstrated that patients with spasmodic dysphonia have decreased RAC binding to $\mathrm{D}_{2} / \mathrm{D}_{3}$ receptors in the bilateral striatum during resting, which is associated with a significantly decreased RAC displacement in the left striatum during symptomatic speech production, but increased RAC displacement in the bilateral striatum during asymptomatic motor task performance. These alterations in task-dependent dopaminergic 
Table 2. Significant differences in striatal RAC BP at rest and its changes during task production

\begin{tabular}{|c|c|c|c|c|c|}
\hline Striatum divisions & $\begin{array}{l}\mathrm{RACBP}_{\mathrm{ND}} \\
\text { (spasmodic dysphonia/ } \\
\text { healthy controls) }\end{array}$ & $\begin{array}{l}\text { Group difference in } \\
\text { RAC BP- }_{\text {ND }} \text { (spasmodic } \\
\text { dysphonia }<\text { HV) (\%) }\end{array}$ & $\begin{array}{l}\Delta \text { RAC BP } \\
\text { (spasmodic dysphonia/ } \\
\text { healthy controls) (\%) }\end{array}$ & $\begin{array}{l}\text { Group difference in } \\
\triangle R A C B P(\text { spasmodic } \\
\text { dysphonia }<\text { HV) (\%) }\end{array}$ & $\begin{array}{l}\text { Group difference in } \\
\Delta \text { RAC BP (spasmodic } \\
\text { dysphonia }>\text { HV) (\%) }\end{array}$ \\
\hline \multicolumn{6}{|l|}{ Baseline } \\
\hline R putamen & $1.7 \pm 0.5 / 2.3 \pm 0.4$ & 25.7 & & & \\
\hline L caudate & $1.0 \pm 0.5 / 1.5 \pm 0.4$ & 31.8 & & & \\
\hline R caudate & $0.9 \pm 0.5 / 1.3 \pm 0.3$ & 33.6 & & & \\
\hline L caudate & $0.9 \pm 0.4 / 1.0 \pm 0.2$ & & $-3.5 /-17.2$ & 13.7 & \\
\hline \multicolumn{6}{|c|}{ Asymptomatic finger tapping } \\
\hline L putamen & $1.6 \pm 0.5 / 2.3 \pm 0.4$ & & $-11.0 /-1.5$ & & 9.6 \\
\hline R putamen & $1.7 \pm 0.7 / 2.4 \pm 0.4$ & & $-11.0 /-5.3$ & & 5.7 \\
\hline L caudate & $0.6 \pm 0.3 / 1.0 \pm 0.4$ & & $-17.9 /-2.9$ & & 15.0 \\
\hline R caudate & $0.8 \pm 0.4 / 1.4 \pm 0.4$ & & $-10.8 /-0.9$ & & 10.0 \\
\hline
\end{tabular}

\section{Relationship between speech-induced dopamine release and duration}
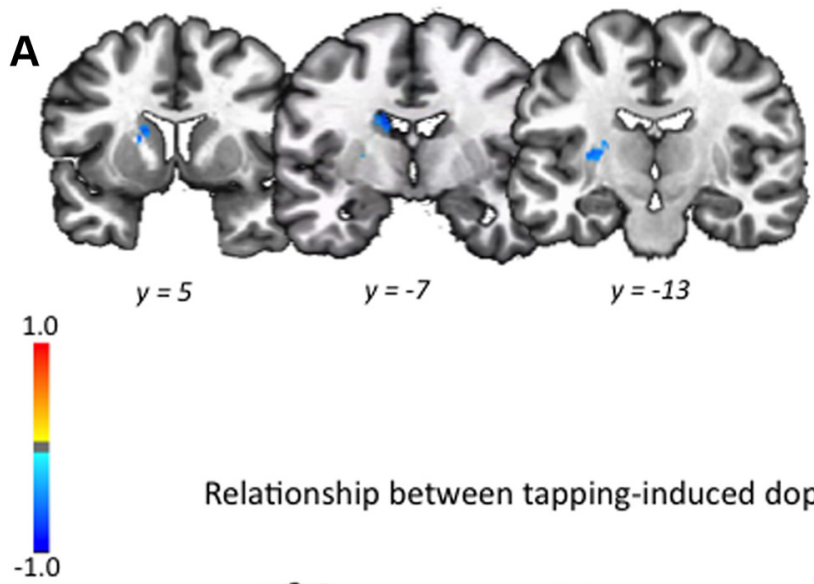

$\begin{array}{ll}y=-7 & y=-13\end{array}$

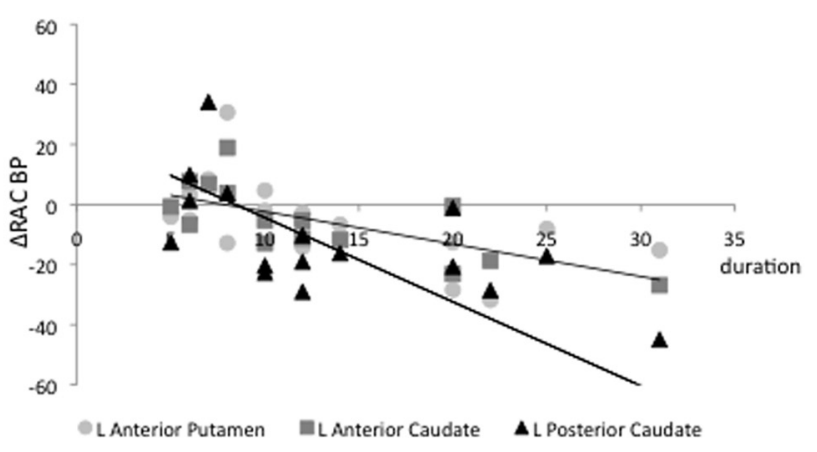

Relationship between tapping-induced dopamine release and duration
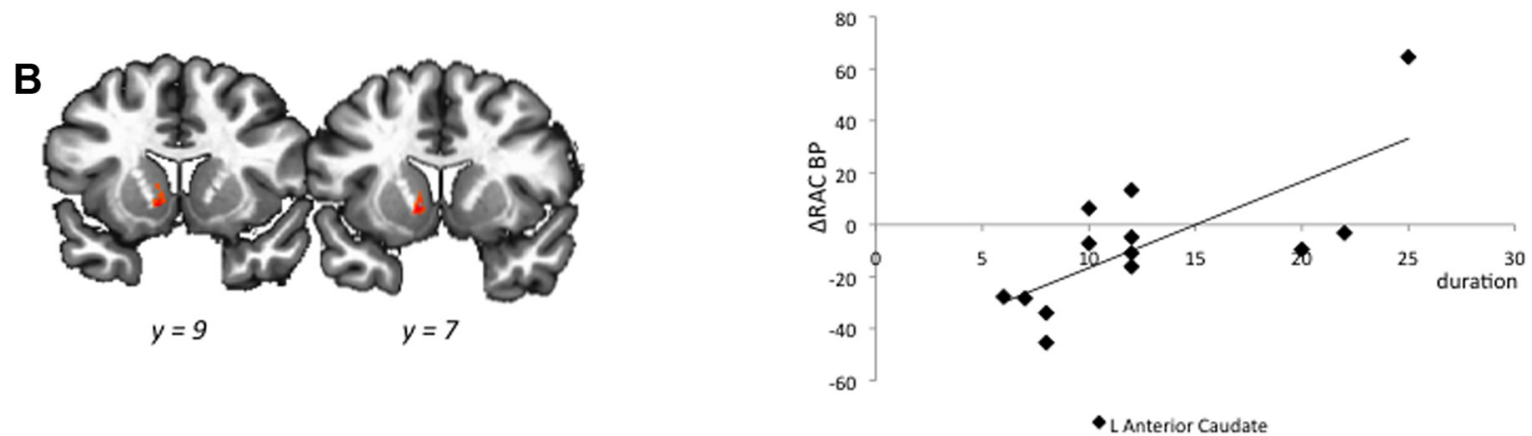

Figure 3. $\quad A, B$, Relationships between the duration of spasmodic dysphonia (in years) and mean percentage change in $\left[{ }^{11} \mathrm{C}\right]$ raclopride binding potential during symptomatic speech production $(\boldsymbol{A})$ and asymptomatic sequential finger tapping $(\boldsymbol{B})$. The color bar represents the $r_{s}$ values. Correlations are shown in the series of coronal brain images in Talairach-Tournoux standard space.

function establish significant relationships with the severity and duration of spasmodic dysphonia and may contribute to the pathophysiology of this disorder.

While there is no apparent neurodegeneration or cell loss within the basal ganglia (Standaert, 2011), experimentally, reduced striatal $\mathrm{D}_{2}$ receptor binding has been observed in the $d t^{s z}$ mutant hamster (Nobrega et al., 1996) and associated with increased striatal dopamine release during the manifestation of dystonic episodes (Hamann and Richter, 2004). In contrast, the DYT1 dystonia mouse model exhibited normal striatal $\mathrm{D}_{2}$ receptor binding (Balcioglu et al., 2007; Zhao et al., 2008) with the range of unchanged, increased, or decreased levels of striatal dopamine release during dystonic-like movements (Dang et al., 2005, 2006; Shashidharan et al., 2005; Balcioglu et al., 2007; Grundmann et al., 2007; Yokoi et al., 2008, 2011; Zhao et al., 2008; Page et al., 2010; Song et al., 2012). Although conflicting to 


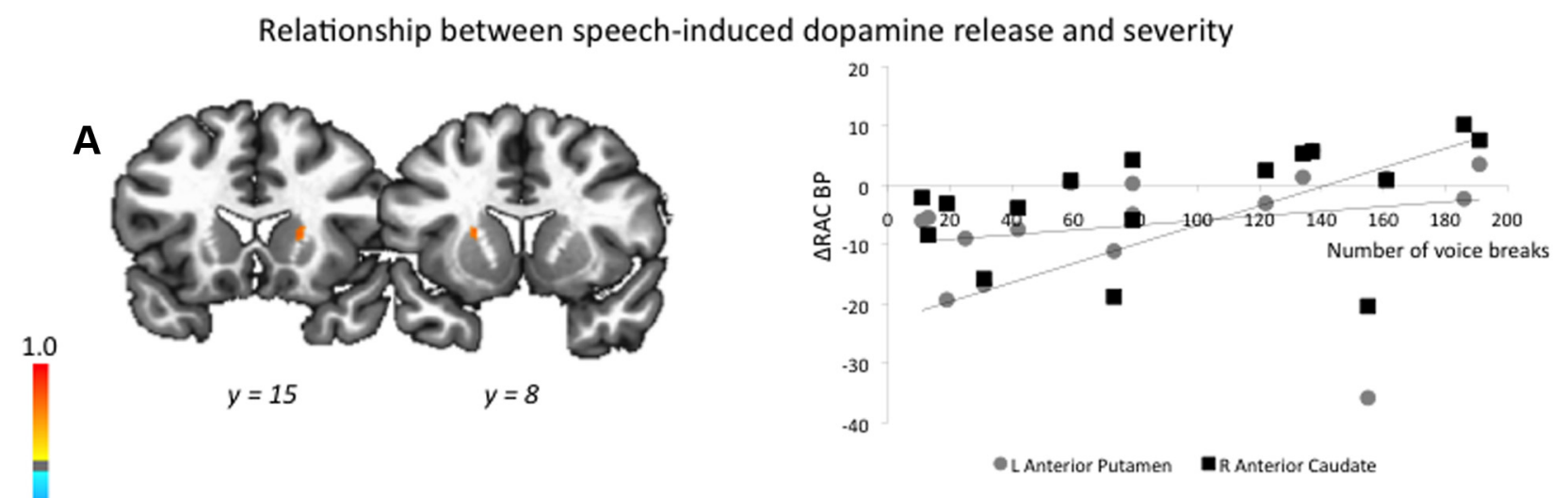

Relationship between tapping-induced dopamine release and reaction time
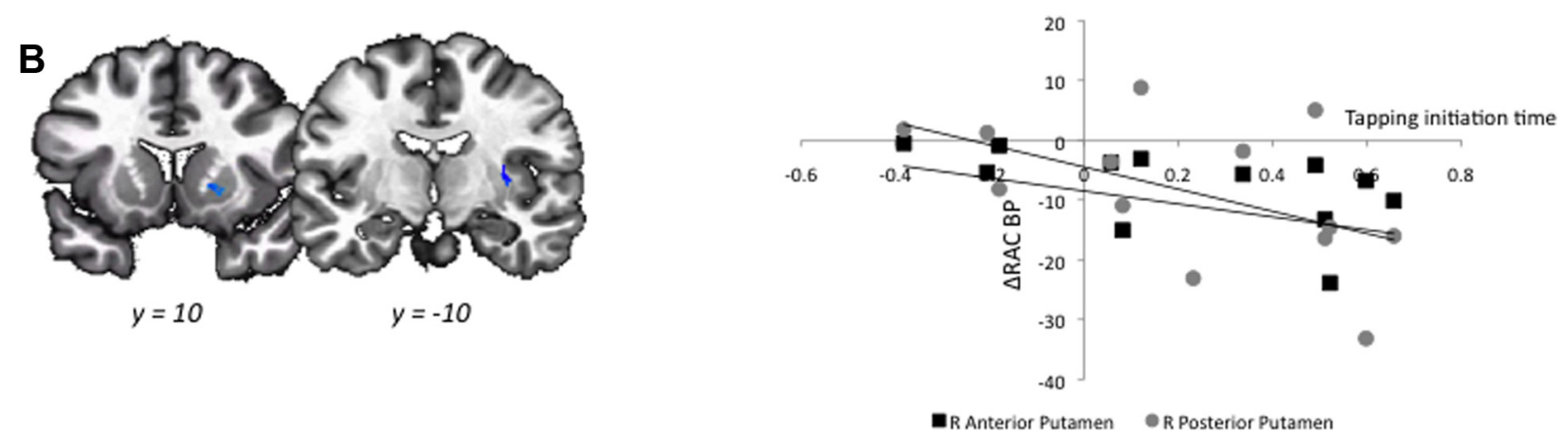

Figure 4. $\quad A, B$, Relationship between the clinical/subclinical characteristics of spasmodic dysphonia and mean percentage change in $\left[{ }^{11} \mathrm{C}\right]$ raclopride binding potential during symptomatic speech production $(\boldsymbol{A})$ and asymptomatic sequential finger tapping $(\boldsymbol{B})$. Spasmodic dysphonia severity was measured as a number of voice breaks in produced sentences. Delayed initiation time of tapping execution was found in patients compared to controls. The color bar represents the $r_{s}$ values. Correlations are shown in the series of coronal brain images in Talairach-Tournoux standard space.

some extent, these results are in agreement that dopaminergic neurotransmission is affected in dystonia and may vary between the resting and dystonic states.

\section{Decreased RAC binding to striatal dopamine $D_{2 / 3}$ receptors during resting in patients with spasmodic dysphonia}

In patients, decreased striatal dopamine $\mathrm{D}_{2} / \mathrm{D}_{3}$ receptor binding has commonly been found across different forms of primary dystonia (Horstink et al., 1997; Perlmutter et al., 1997; Naumann et al., 1998; Augood et al., 2002; Asanuma et al., 2005; Berger et al., 2007; Carbon et al., 2009; Horie et al., 2009). In agreement with these reports, we showed, on average, a 29.2\% decrease in RAC binding to dopamine $\mathrm{D}_{2} / \mathrm{D}_{3}$ receptors in the bilateral striatum during resting when patients with spasmodic dysphonia did not exhibit any symptoms and were not engaged in any task.

Decreased RAC BP at rest is thought to reflect decreased $\mathrm{D}_{2} / \mathrm{D}_{3}$ receptor availability due to decreased receptor density and/or increased tonic dopamine levels in the synapses (Seeman et al., 1989; Volkow et al., 1994). This may contribute to disinhibition within the indirect basal ganglia pathway and lead to an inability to suppress unwanted "nearby" motor contractions during the production of specific actions, a well-established abnormality in primary dystonia (Hallett, 2011). Both decreased receptor density and increased tonic dopamine levels occupying and stimulating $\mathrm{D}_{2} / \mathrm{D}_{3}$ receptors may further alter RAC displacement during pharmacological challenge or task production (Doudet and Holden, 2003; Egerton et al., 2009).

RAC binding to dopamine $\mathrm{D}_{2} / \mathrm{D}_{3}$ receptors may also be decreased because of the ligand's potential to bind to surface recep- tors only and inability to access the pool of internalized receptors (Laruelle, 2000; Ginovart, 2005). A previous PET study using $\left[{ }^{18} \mathrm{~F}\right]$ spiperone, which has an access to both surface and internalized $\mathrm{D}_{2} / \mathrm{D}_{3}$ receptors, reported a $29 \%$ decrease in receptor binding at rest in cranial and hand dystonia (Perlmutter et al., 1997), similar to our findings of decreased RAC binding at rest in spasmodic dysphonia. Together, these data imply that, in patients, the resting binding of the radioligand is likely decreased to both surface and internalized receptors and may not be due to the differences in the receptor internalization rate.

\section{Abnormal RAC $\triangle \mathrm{BP}_{\mathrm{ND}}$ during task production in patients with spasmodic dysphonia}

Numerous studies in humans and animals over the past two decades have confirmed that the variations in the level of RAC binding to $\mathrm{D}_{2} / \mathrm{D}_{3}$ receptors depend on the levels of drug- and/or behavior-induced synaptic dopamine release (for review, see Laruelle, 2000; Ginovart, 2005; Egerton et al., 2009). In patients with spasmodic dysphonia compared to controls, we found, on average, a $10.2 \%$ decrease in RAC $\Delta \mathrm{BP}_{\mathrm{ND}}$ in the left striatum during symptomatic speaking, but a $10.1 \%$ increase in RAC $\triangle \mathrm{BP}_{\mathrm{ND}}$ in the bilateral striatum during asymptomatic finger tapping. Potentially, decreased RAC binding at rest in patients with spasmodic dysphonia may obscure decreases in RAC displacement due to dopamine release during task production. While the possibility of such floor effect cannot be ruled out, typically, decreased RAC $\triangle \mathrm{BP}_{\mathrm{ND}}$ is considered to reflect decreased phasic dopaminergic activity and may represent a disorder-specific pathophysiological trait involved in generation of symptoms of 
spasmodic dysphonia. On the other hand, increased RAC $\Delta \mathrm{BP}_{\mathrm{ND}}$, reflecting increased dopamine release during unrelated and unaffected motor task performance, may be explained by a compensatory adaptation of the nigrostriatal dopaminergic system due to decreased striatal $\mathrm{D}_{2} / \mathrm{D}_{3}$ receptor availability. In support of our findings of bidirectional fluctuations in taskdependent dopaminergic activity, similar observations in patients with another form of primary focal dystonia, writer's cramp, also demonstrated decreased RAC $\Delta \mathrm{BP}_{\mathrm{ND}}$ during symptom production, but increased RAC $\triangle \mathrm{BP}_{\mathrm{ND}}$ during an asymptomatic task in the presence of decreased RAC binding to $\mathrm{D}_{2} / \mathrm{D}_{3}$ receptors at rest (Berman et al., 2013). It appears that neurochemical alterations in primary dystonias may involve not only impaired dopaminergic modulation of an affected task, but also more "global" abnormalities of $\mathrm{D}_{2} / \mathrm{D}_{3}$ receptor structure and function at the both resting and unaffected task production states.

We demonstrated that, during symptomatic speech production, patients with spasmodic dysphonia had impaired dopaminergic function in the left striatum only. A series of experimental, clinical, and neuroimaging studies have shown that the putamen and head of the caudate nucleus are critical for the control of learned voice production, such as speech and song, but not innate emotional vocalizations, such as laughter and cry (Damasio et al., 1982; Jurgens et al., 1982; Cummings, 1993; Lee et al., 1996; Nadeau and Crosson, 1997; Watkins et al., 2002; Price, 2010). Notably, speech is affected in patients with spasmodic dysphonia, while laughter and cry are not. Brain imaging studies showed the greater involvement of the left putamen in speech initiation, speed of learned voice production, semantic processing, and verbal semantic and episodic memory, while the caudate nucleus appears to be responsible for suppression of unintended responses and monitoring phonological accuracy during speaking (Riecker et al., 2005; Tettamanti et al., 2005; Köylü et al., 2006; Davis and Gaskell, 2009; Price, 2010; Ystad et al., 2010). Recently, it was shown that speech-induced striatal dopamine release in healthy humans is left-lateralized and establishes a significant relationship with neural activity in the left putamen and influences the left-hemispheric lateralization of striatal functional networks (Simonyan et al., 2013). Our data suggest that decreased dopamine release in the left putamen of patients during symptomatic speech production may underlie abnormal motor voice control, whereas the production of spasmodic dysphoniacharacteristic voice breaks might lead to persistent negative feedback engaging the caudate nucleus for error feedback monitoring. This may cause pauses in firing of dopaminergic neurons, which, in turn, may result in decreased dopamine release during symptom production.

On the other hand, sustained increases in striatal dopamine release during asymptomatic sequential finger tapping unrelated to voice symptoms may represent a subclinical feature of spasmodic dysphonia. Involvement of the bilateral striatum may be explained by a possible need to compensate for bilateral structural and/or functional abnormalities at the level of $\mathrm{D}_{2} / \mathrm{D}_{3}$ receptors to maintain the production of an unaffected task. The breakdown of this compensatory mechanism at the neurochemical level might lead to the spread of dystonic symptoms to the other body regions. This assumption needs to be confirmed in follow-up studies.

\section{Clinical correlations}

The duration of spasmodic dysphonia had significant correlations with RAC displacement during production of both symptomatic and asymptomatic tasks. This indicates that abnormalities of task- related dopaminergic function may evolve over the course of disorder. Particularly, decreased levels of speech-induced dopamine release in the left posterior putamen were associated with the early years of spasmodic dysphonia, whereas abnormal dopamine release in the left anterior caudate nucleus during speaking and finger tapping was correlated with longer duration of spasmodic dysphonia. These findings point to early impairment of the habitual basal ganglia control (via the involvement of the posterior putamen), which, when present over many years, appears to recruit additional abnormalities within the goal-directed control system (via the involvement of the anterior caudate nucleus).

In addition, patients with greater symptom severity and longer reaction time to initiate tapping had higher levels of striatal dopamine release. While the causes of such relationships are not entirely clear, they may reflect increased motor demands in more severe patients with higher number of dystonic voice breaks, requiring compensatory increases of dopamine release to manage greater symptoms.

\section{Summary}

In summary, the presence of global dopaminergic abnormalities during the resting state as well as symptomatic/asymptomatic tasks may reflect the neurochemical underpinnings of both spasmodic dysphonia-specific and dystonia-common pathophysiological processes, such as loss of inhibition, abnormal sensorimotor integration, and maladaptive plasticity (Stamelou et al., 2012). Furthermore, our findings of correlations between the clinical/subclinical features of spasmodic dysphonia and alterations in striatal dopaminergic function provide direct evidence for the impact of neurochemical dysfunction on the development of this disorder.

\section{References}

Aronson A (1990) Clinical voice disorders: an interdisciplinary approach, Ed 3. New York: Thieme.

Asanuma K, Ma Y, Okulski J, Dhawan V, Chaly T, Carbon M, Bressman SB, Eidelberg D (2005) Decreased striatal D2 receptor binding in nonmanifesting carriers of the DYT1 dystonia mutation. Neurology 64:347349. CrossRef Medline

Augood SJ, Hollingsworth Z, Albers DS, Yang L, Leung JC, Muller B, Klein C, Breakefield XO, Standaert DG (2002) Dopamine transmission in DYT1 dystonia: a biochemical and autoradiographical study. Neurology 59: 445-448. CrossRef Medline

Balcioglu A, Kim MO, Sharma N, Cha JH, Breakefield XO, Standaert DG (2007) Dopamine release is impaired in a mouse model of DYT1 dystonia. J Neurochem 102:783-788. CrossRef Medline

Barkmeier JM, Case JL, Ludlow CL (2001) Identification of symptoms for spasmodic dysphonia and vocal tremor: a comparison of expert and nonexpert judges. J Commun Disord 34:21-37. CrossRef Medline

Berardelli A, Rothwell JC, Hallett M, Thompson PD, Manfredi M, Marsden CD (1998) The pathophysiology of primary dystonia. Brain 121:11951212. CrossRef Medline

Berger HJ, van der Werf SP, Horstink CA, Cools AR, Oyen WJ, Horstink MW (2007) Writer's cramp: restoration of striatal D2-binding after successful biofeedback-based sensorimotor training. Parkinsonism Relat Disord 13: 170-173. Medline

Berman BD, Hallett M, Herscovitch P, Simonyan K (2013) Striatal dysfunction at rest and during task performance in writer's cramp. Brain. In press.

Bielamowicz S, Ludlow CL (2000) Effects of botulinum toxin on pathophysiology in spasmodic dysphonia. Ann Otol Rhinol Laryngol 109:194203. Medline

Bloch CS, Hirano M, Gould WJ (1985) Symptom improvement of spastic dysphonia in response to phonatory tasks. Ann Otol Rhinol Laryngol 94:51-54. Medline

Breakefield XO, Blood AJ, Li Y, Hallett M, Hanson PI, Standaert DG (2008) The pathophysiological basis of dystonias. Nat Rev Neurosci 9:222-234. CrossRef Medline

Breier A, Su TP, Saunders R, Carson RE, Kolachana BS, de Bartolomeis A, 
Weinberger DR, Weisenfeld N, Malhotra AK, Eckelman WC, Pickar D (1997) Schizophrenia is associated with elevated amphetamine-induced synaptic dopamine concentrations: evidence from a novel positron emission tomography method. Proc Natl Acad Sci U S A 94:2569-2574. CrossRef Medline

Carbon M, Niethammer M, Peng S, Raymond D, Dhawan V, Chaly T, Ma Y, Bressman S, Eidelberg D (2009) Abnormal striatal and thalamic dopamine neurotransmission: genotype-related features of dystonia. Neurology 72:2097-2103. CrossRef Medline

Carson RE, Breier A, de Bartolomeis A, Saunders RC, Su TP, Schmall B, Der MG, Pickar D, Eckelman WC (1997) Quantification of amphetamineinduced changes in $[11 \mathrm{C}]$ raclopride binding with continuous infusion. J Cereb Blood Flow Metab 17:437-447. Medline

Cummings JL (1993) Frontal-subcortical circuits and human behavior. Arch Neurol 50:873-880. CrossRef Medline

Damasio AR, Damasio H, Rizzo M, Varney N, Gersh F (1982) Aphasia with nonhemorrhagic lesions in the basal ganglia and internal capsule. Arch Neurol 39:15-24. CrossRef Medline

Dang MT, Yokoi F, McNaught KS, Jengelley TA, Jackson T, Li J, Li Y (2005) Generation and characterization of Dyt1 DeltaGAG knock-in mouse as a model for early-onset dystonia. Exp Neurol 196:452-463. CrossRef Medline

Dang MT, Yokoi F, Pence MA, Li Y (2006) Motor deficits and hyperactivity in Dyt1 knockdown mice. Neurosci Res 56:470-474. CrossRef Medline

Davis MH, Gaskell MG (2009) A complementary systems account of word learning: neural and behavioural evidence. Philos Trans R Soc Lond B Biol Sci 364:3773-3800. CrossRef Medline

Defazio G, Berardelli A, Hallett M (2007) Do primary adult-onset focal dystonias share aetiological factors? Brain 130:1183-1193. CrossRef Medline

del Campo N, Tait RJ, Acosta-Cabronero J, Hong YT, Izquierdo-Garcia D, Smith R, Aigbirhio FI, Sahakian BJ, Müller U, Robbins TW, Fryer TD (2011) Quantification of receptor-ligand binding potential in substriatal domains using probabilistic and template regions of interest. Neuroimage 55:101-112. Medline

Doudet DJ, Holden JE (2003) Raclopride studies of dopamine release: dependence on presynaptic integrity. Biol Psychiatry 54:1193-1199. CrossRef Medline

Egerton A, Mehta MA, Montgomery AJ, Lappin JM, Howes OD, Reeves SJ, Cunningham VJ, Grasby PM (2009) The dopaminergic basis of human behaviors: A review of molecular imaging studies. Neurosci Biobehav Rev 33:1109-1132. CrossRef Medline

Eickhoff SB, Stephan KE, Mohlberg H, Grefkes C, Fink GR, Amunts K, Zilles K (2005) A new SPM toolbox for combining probabilistic cytoarchitectonic maps and functional imaging data. Neuroimage 25:1325-1335. CrossRef Medline

Forman SD, Cohen JD, Fitzgerald M, Eddy WF, Mintun MA, Noll DC (1995) Improved assessment of significant activation in functional magnetic resonance imaging (fMRI): use of a cluster-size threshold. Magn Reson Med 33:636-647. Medline

Garraux G, Peigneux P, Carson RE, Hallett M (2007) Task-related interaction between basal ganglia and cortical dopamine release. J Neurosci 27: 14434-14441. CrossRef Medline

Ginovart N (2005) Imaging the dopamine system with in vivo [11C]raclopride displacement studies: understanding the true mechanism. Mol Imaging Biol 7:45-52. CrossRef Medline

Grundmann K, Reischmann B, Vanhoutte G, Hübener J, Teismann P, Hauser TK, Bonin M, Wilbertz J, Horn S, Nguyen HP, Kuhn M, Chanarat S, Wolburg H, Van der Linden A, Riess O (2007) Overexpression of human wildtype torsinA and human DeltaGAG torsinA in a transgenic mouse model causes phenotypic abnormalities. Neurobiol Dis 27:190206. CrossRef Medline

Hallett M (1998) The neurophysiology of dystonia. Arch Neurol 55:601603. CrossRef Medline

Hallett M (2004) Dystonia: abnormal movements result from loss of inhibition. Adv Neurol 94:1-9. Medline

Hallett M (2011) Neurophysiology of dystonia: the role of inhibition. Neurobiol Dis 42:177-184. CrossRef Medline

Hamann M, Richter A (2004) Striatal increase of extracellular dopamine levels during dystonic episodes in a genetic model of paroxysmal dyskinesia. Neurobiol Dis 16:78-84. CrossRef Medline

Horie C, Suzuki Y, Kiyosawa M, Mochizuki M, Wakakura M, Oda K, Ishiwata
K, Ishii K (2009) Decreased dopamine D receptor binding in essential blepharospasm. Acta Neurol Scand 119:49-54. CrossRef Medline

Horstink CA, Praamstra P, Horstink MW, Berger HJ, Booij J, Van Royen EA (1997) Low striatal D2 receptor binding as assessed by [123I]IBZM SPECT in patients with writer's cramp. J Neurol Neurosurg Psychiatry 62:672-673. CrossRef Medline

Horwitz B, Duara R, Rapoport SI (1986) Age differences in intercorrelations between regional cerebral metabolic rates for glucose. Ann Neurol 19:60 67. CrossRef Medline

Horwitz B, Swedo SE, Grady CL, Pietrini P, Schapiro MB, Rapoport JL, Rapoport SI (1991) Cerebral metabolic pattern in obsessivecompulsive disorder: altered intercorrelations between regional rates of glucose utilization. Psychiatry Res 40:221-237. CrossRef Medline

Izdebski K, Dedo HH, Boles L (1984) Spastic dysphonia: a patient profile of 200 cases. Am J Otolaryngol 5:7-14. CrossRef Medline

Jürgens U, Kirzinger A, von Cramon D (1982) The effects of deep-reaching lesions in the cortical face area on phonation. A combined case report and experimental monkey study. Cortex 18:125-139. CrossRef Medline

Köylü B, Trinka E, Ischebeck A, Visani P, Trieb T, Kremser C, Bartha L, Schocke M, Benke T (2006) Neural correlates of verbal semantic memory in patients with temporal lobe epilepsy. Epilepsy Res 72:178-191. CrossRef Medline

Laruelle M (2000) Imaging synaptic neurotransmission with in vivo binding competition techniques: a critical review. J Cereb Blood Flow Metab 20: 423-451. Medline

Lee MS, Lee SB, Kim WC (1996) Spasmodic dysphonia associated with a left ventrolateral putaminal lesion. Neurology 47:827-828. CrossRef Medline

Lenz FA, Suarez JI, Metman LV, Reich SG, Karp BI, Hallett M, Rowland LH, Dougherty PM (1998) Pallidal activity during dystonia: somatosensory reorganisation and changes with severity. J Neurol Neurosurg Psychiatry 65:767-770. CrossRef Medline

Nadeau SE, Crosson B (1997) Subcortical aphasia. Brain Lang 58:355-402; discussion 418-423. Medline

Naumann M, Pirker W, Reiners K, Lange KW, Becker G, Brücke T (1998) Imaging the pre- and postsynaptic side of striatal dopaminergic synapses in idiopathic cervical dystonia: a SPECT study using [123I] epidepride and [123I] beta-CIT. Mov Disord 13:319-323. CrossRef Medline

Neychev VK, Gross RE, Lehéricy S, Hess EJ, Jinnah HA (2011) The functional neuroanatomy of dystonia. Neurobiol Dis 42:185-201. CrossRef Medline

Nobrega JN, Richter A, Tozman N, Jiwa D, Löscher W (1996) Quantitative autoradiography reveals regionally selective changes in dopamine D1 and D2 receptor binding in the genetically dystonic hamster. Neuroscience 71:927-937. CrossRef Medline

Oldfield RC (1971) The assessment and analysis of handedness: the Edinburgh inventory. Neuropsychologia 9:97-113. CrossRef Medline

Page ME, Bao L, Andre P, Pelta-Heller J, Sluzas E, Gonzalez-Alegre P, Bogush A, Khan LE, Iacovitti L, Rice ME, Ehrlich ME (2010) Cell-autonomous alteration of dopaminergic transmission by wild type and mutant (DeltaE) TorsinA in transgenic mice. Neurobiol Dis 39:318-326. CrossRef Medline

Perlmutter JS, Stambuk MK, Markham J, Black KJ, McGee-Minnich L, Jankovic J, Moerlein SM (1997) Decreased [18F] spiperone binding in putamen in idiopathic focal dystonia. J Neurosci 17:843-850. Medline

Peterson DA, Sejnowski TJ, Poizner H (2010) Convergent evidence for abnormal striatal synaptic plasticity in dystonia. Neurobiol Dis 37:558-573. CrossRef Medline

Price CJ (2010) The anatomy of language: a review of 100 fMRI studies published in 2009. Ann N Y Acad Sci 1191:62-88. CrossRef

Riecker A, Mathiak K, Wildgruber D, Erb M, Hertrich I, Grodd W, Ackermann H (2005) fMRI reveals two distinct cerebral networks subserving speech motor control. Neurology 64:700-706. CrossRef Medline

Salimpoor VN, Benovoy M, Larcher K, Dagher A, Zatorre RJ (2011) Anatomically distinct dopamine release during anticipation and experience of peak emotion to music. Nat Neurosci 14:257-262. CrossRef Medline

Seeman P, Guan HC, Niznik HB (1989) Endogenous dopamine lowers the dopamine $\mathrm{D} 2$ receptor density as measured by $[3 \mathrm{H}]$ raclopride: implications for positron emission tomography of the human brain. Synapse 3:96-97. CrossRef Medline

Shashidharan P, Sandu D, Potla U, Armata IA, Walker RH, McNaught KS, Weisz D, Sreenath T, Brin MF, Olanow CW (2005) Transgenic mouse 
model of early-onset DYT1 dystonia. Hum Mol Genet 14:125-133. Medline

Simonyan K, Ludlow CL (2010) Abnormal activation of the primary somatosensory cortex in spasmodic dysphonia: an FMRI study. Cereb Cortex 20:2749-2759. CrossRef Medline

Simonyan K, Herscovitch P, Horwitz B (2013) Speech-induced striatal dopamine release is left lateralized and coupled to functional striatal circuits in healthy humans: A combined PET, fMRI and DTI study. Neuroimage 70:21-32. CrossRef Medline

Song CH, Fan X, Exeter CJ, Hess EJ, Jinnah HA (2012) Functional analysis of dopaminergic systems in a DYT1 knock-in mouse model of dystonia. Neurobiol Dis 48:66-78. CrossRef Medline

Stamelou M, Edwards MJ, Hallett M, Bhatia KP (2012) The non-motor syndrome of primary dystonia: clinical and pathophysiological implications. Brain 135:1668-1681. CrossRef Medline

Standaert DG (2011) Update on the pathology of dystonia. Neurobiol Dis 42:148-151. CrossRef Medline

Tanner K, Roy N, Merrill RM, Sauder C, Houtz DR, Smith ME (2011) Spasmodic dysphonia: onset, course, socioemotional effects, and treatment response. Ann Otol Rhinol Laryngol 120:465-473. Medline

Tettamanti M, Moro A, Messa C, Moresco RM, Rizzo G, Carpinelli A, Matarrese M, Fazio F, Perani D (2005) Basal ganglia and language: phonology modulates dopaminergic release. Neuroreport 16:397-401. CrossRef Medline

Todd RD, Perlmutter JS (1998) Mutational and biochemical analysis of dopamine in dystonia: evidence for decreased dopamine D2 receptor inhibition. Mol Neurobiol 16:135-147. CrossRef Medline

Volkow ND, Wang GJ, Fowler JS, Logan J, Schlyer D, Hitzemann R, Lieberman J, Angrist B, Pappas N, MacGregor R (1994) Imaging endogenous dopamine competition with [11C]raclopride in the human brain. Synapse 16:255-262. CrossRef Medline

Watabe H, Endres CJ, Breier A, Schmall B, Eckelman WC, Carson RE (2000) Measurement of dopamine release with continuous infusion of [11C]raclopride: optimization and signal-to-noise considerations. J Nucl Med 41:522-530. Medline

Watkins KE, Dronkers NF, Vargha-Khadem F (2002) Behavioural analysis of an inherited speech and language disorder: comparison with acquired aphasia. Brain 125:452-464. CrossRef

Wong DF, Brasić JR, Singer HS, Schretlen DJ, Kuwabara H, Zhou Y, Nandi A, Maris MA, Alexander M, Ye W, Rousset O, Kumar A, Szabo Z, Gjedde A, Grace AA (2008) Mechanisms of dopaminergic and serotonergic neurotransmission in Tourette syndrome: clues from an in vivo neurochemistry study with PET. Neuropsychopharmacology 33: 1239-1251. CrossRef Medline

Yokoi F, Dang MT, Mitsui S, Li J, Li Y (2008) Motor deficits and hyperactivity in cerebral cortex-specific Dyt1 conditional knockout mice. J Biochem 143:39-47. Medline

Yokoi F, Dang MT, Li J, Standaert DG, Li Y (2011) Motor deficits and decreased striatal dopamine receptor 2 binding activity in the striatumspecific Dytl conditional knockout mice. PLoS One 6:e24539. CrossRef Medline

Ystad M, Eichele T, Lundervold AJ, Lundervold A (2010) Subcortical functional connectivity and verbal episodic memory in healthy elderly-a resting state fMRI study. Neuroimage 52:379-388. CrossRef Medline

Zhao Y, DeCuypere M, LeDoux MS (2008) Abnormal motor function and dopamine neurotransmission in DYT1 DeltaGAG transgenic mice. Exp Neurol 210:719-730. CrossRef Medline 